\title{
THE ECOLOGICAL SIGNIFICANCE OF SEASONAL OCCURRENCE AND GROWTH RATE OF VELELLA (HYDROZOA)
}

\section{$\operatorname{AUTHOR(S):~}$}

Bieri, Robert

\section{CITATION:}

Bieri, Robert. THE ECOLOGICAL SIGNIFICANCE OF SEASONAL OCCURRENCE AND GROWTH RATE OF VELELLA (HYDROZOA). PUBLICATIONS OF THE SETO MARINE BIOLOGICAL LABORATORY 1977, 24(1-3): 63-76

\section{ISSUE DATE:}

1977-11-30

URL:

http://hdl.handle.net/2433/175957

RIGHT: 


\title{
THE EGOLOGIGAL SIGNIFIGANGE OF SEASONAL OCGURRENCE AND GROWTH RATE OF VELELLA (HYDROZOA)
}

\author{
ROBERT BIERI \\ Antioch College, Yellow Springs, Ohio 45387
}

With Text-figures 1-9 and Tables 1-2

The sudden unpredictable occurrence of oceanic neuston on beaches around the world has stimulated yet greatly hindered the study of neuston biology. Part of this apparently haphazard occurrence is due to the complexity of sorting processes in coastal areas (Woodcock, 1956). The difficulty of studying left and right handedness in stranded Physalia lead to Woodcock's laudable plea for more studies at sea. However the scientist on board ship is often as frustrated at the scattered and sporadic occurrence of neuston as his colleagues ashore. Savilov (1958) had the good fortune to cruise through Velella, Janthina and other animals of the sea surface community for weeks. Bigelow (1911) on the other hand reported that during the Albatross Expedition of 1904-05 only one large Velella was sighted. Thus with everything ready the neustologist may cruise for days or weeks and find not a trace of the larger species. Then unexpectedly in the middle of another research program huge swarms may appear (see for example Doe, 1955), but problems of time, schedule, personnel and equipment may prevent even some random collecting.

These vagaries are not completely whimisical much as they often seem. Bingham and Albertson (1974) have doccumented the importance of wind velocity, duration and direction in beach strandings. Much of the scattered occurrence is also due to "patchiness", a characteristic of plankton in general. It results from the turbulent nature of mixing, from the behavior of the organisms, from predation, food availability and other factors and some of it is due to the scientist's techniques of collection and observation. For example, thrice weekly examination of the beach at Shirahama for eight months amply confirmed the statement of Dakin, Bennett and Pope (1952) that a careful search of newly stranded flotsam reveals a great variety of plants and animals that are there for at most a few hours before being washed again into the sea for final destruction. The data presented below show that Velella has a seasonal pattern of growth and reproduction that accounts in large measure for the vagaries of its appearance. Because it is the food base for many other sea-surface animals (Bieri, 1966; Savilov, 1968) one would expect to find the seasonal occurrence reflected in its cohorts.

Publ. Seto Mar. Biol. Lab., XXIV (1/3), 63-76, $1977 . \quad$ (Article 10) 


\section{Previous Work}

As early as 1870, Spagnolini reported Velella common in the Mediterranean in January and November. Lo Bianco (1899) reported Velella abundant on the surface in the Gulf of Naples from April to June and October to December. However, later (1909) he reported the chrysomitra, conaria and rataria stages abundant throughout the year. Bigelow (1911) accepted Lo Bianco's 1899 report of seasonal occurrence as correct. However, in 1937 Bigelow and Sears stated that Velella "appears at all seasons". Woltereck (1904) demonstrated the vertical migration by sinking of the sexual medusae and later rise to the sea surface of the larval stages. He tentatively accepted the seasonal report of Lo Bianco (1899) as correct but later in the same paper wrote, "Natürlich lässt sich danach noch durchaus nicht entscheiden, ob wir es, wie es immerhin den Anschein hat, mit 2 Generationen zu thun haben, deren erste im Januar als Larven, im Februar als Colonien auftrat, während die von ihren Geschlechtsmedusen erzeugte zweite Generation in den Larven von Angang März und dem jungen Schwarm vom Ende dieses Monats zu suchen wäre." In 1905 Woltereck reported Velella present in the Mediterranean throughout the year. Very significantly Tregouboff and Rose (1957) reported that the adults of Velella blow onto the coasts in April, mostly in May and sometimes in June. Small individuals are found again in August and September. Thus the possibility of seasonal appearance and reproduction has been proposed several times but no clear agreement has been reached.

\section{Methods}

Surface animals were collected at sea off California using a $0.5 \mathrm{~mm}$ mesh net 3.1 meters in circumference and a $0.2 \mathrm{~mm}$ mesh net 1.5 meters in circumference. Both nets were mounted on a rectangular frame equipped with floats so that the nets fished three-quarters of a meter deep, with five $\mathrm{cm}$ of each net always out of the water. The floating net was towed from a boom near the bow of the ship to avoid the wake. At Shirahama a BOOBY II sea-surface sampler (Bieri and Newbury, 1966) was used with a $0.35 \mathrm{~mm}$ mesh net. The $0.5 \mathrm{~mm}$ and $0.35 \mathrm{~mm}$ nets were equipped with flow meters.

When the sea surface community was driven onto the beach, a definite area was marked off and carefully searched on hands and knees. Every specimen was collected with special care given to the search for specimens smaller than ten $\mathrm{mm}$ in maximum dimension. The length of Velella given here is maximum diagonal length of the umbrella on freshly preserved specimens (see Bieri, 1977).

\section{Seasonal Occurrence of Velella}

Bigelow and Sears (1937) lumped all previously described species of Velella into a single world-wide species. However, as Bigelow and earlier workers recog- 
nized (Chun 1897, Bigelow 1911) the Atlantic and Pacific populations can be separated by slight differences in the ratio of skeletal length to width. Bieri (1977) has shown that each different region should be considered separately. However, because

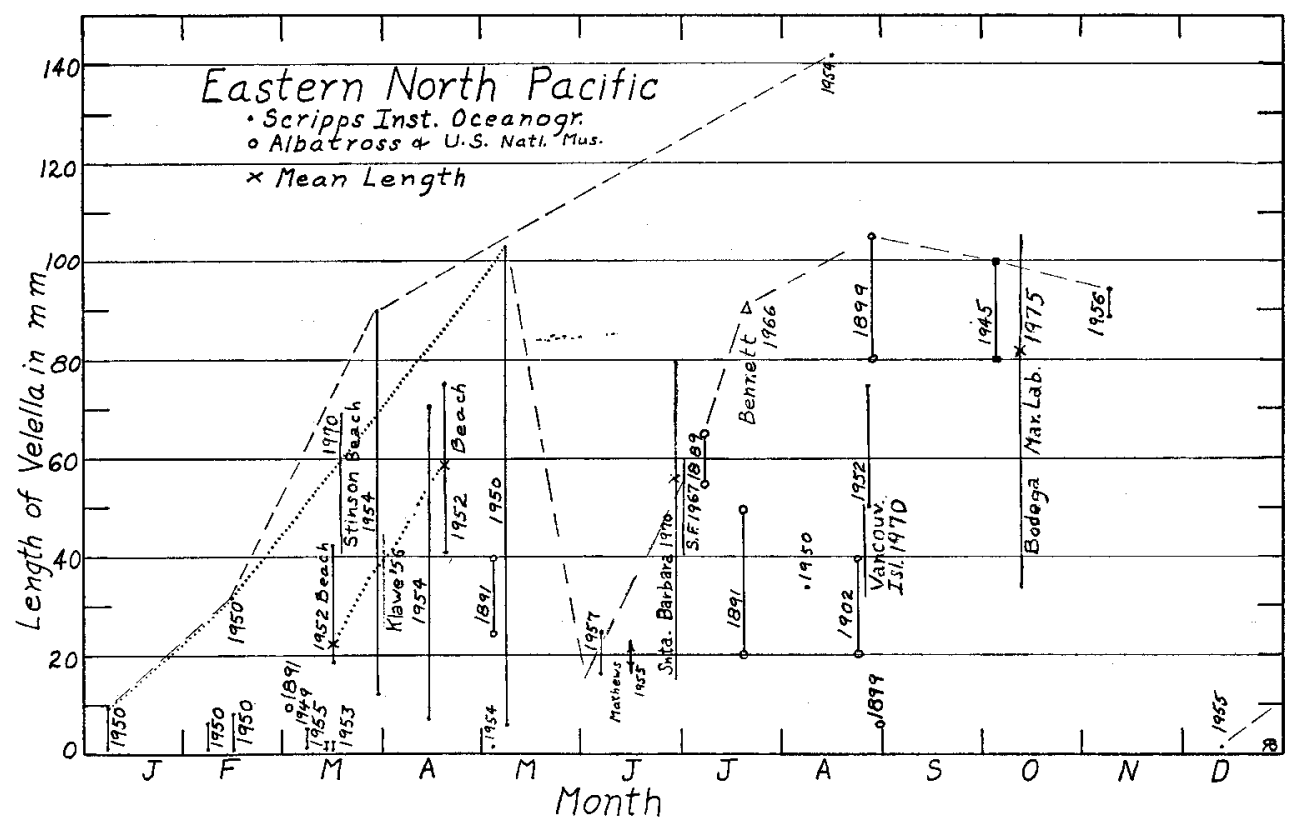

Fig. 1. Records of Velella in the Eastern North Pacific. All S.I.O. records are of left-handed individuals. Handedness is not known in other records. Dotted lines were used to calculate growth rates.

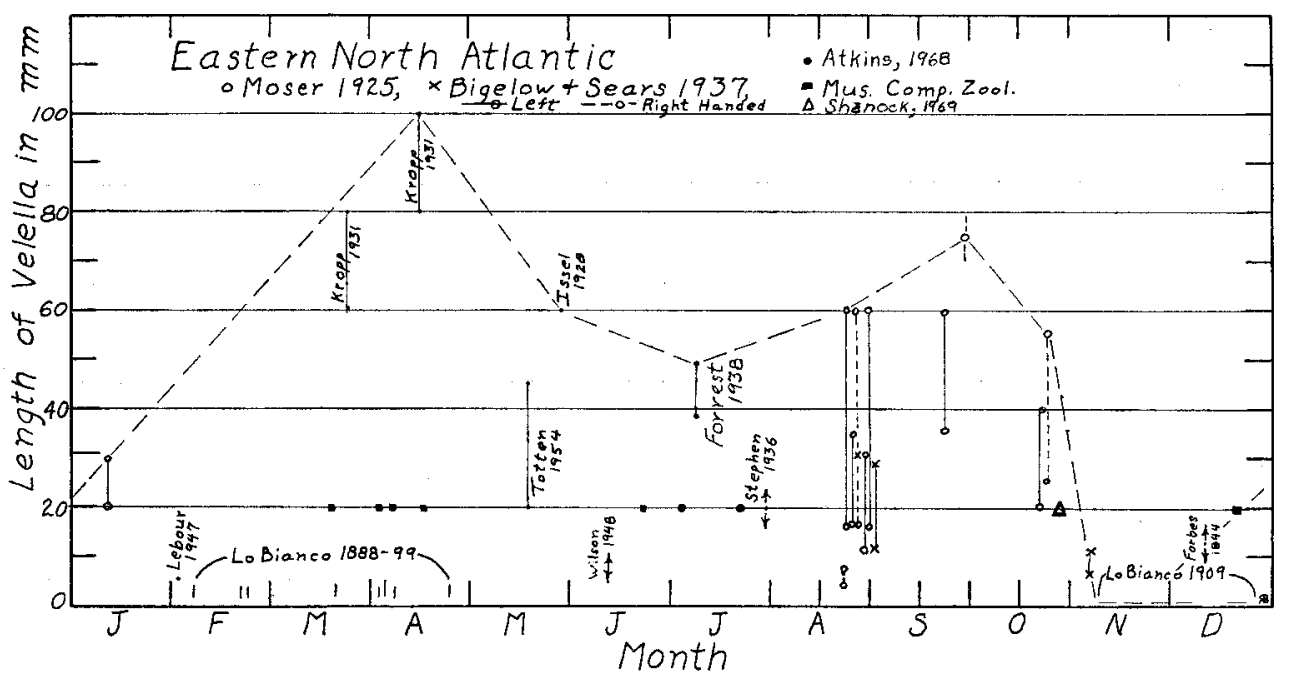

Fig. 2. Records of Velella in the Eastern North Atlantic and Mediterranean Sea. Museum of Comparative Zoology records indicate only the time present-the sizes are not known. 
of the paucity of records, Mediterranean and Eastern North Atlantic records are lumped together as are all records from the southern oceans.

The monthly occurrence of Velella on the sea surface in the Eastern North Pacific

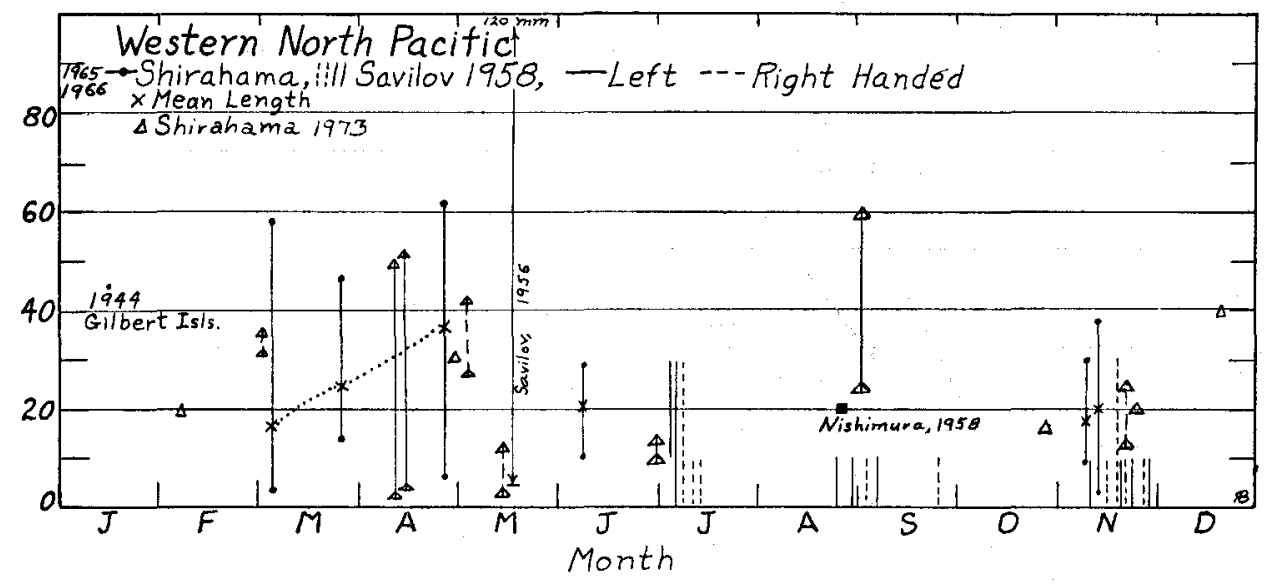

Fig. 3. Records of Velella in the Western North Pacific. The Gilbert Islands record is a single specimen in the U.S. National Museum. The records of Savilov (1958) are interpolated with exact sizes not known. Shirahama records (1965-66) include a few right-handed specimens.

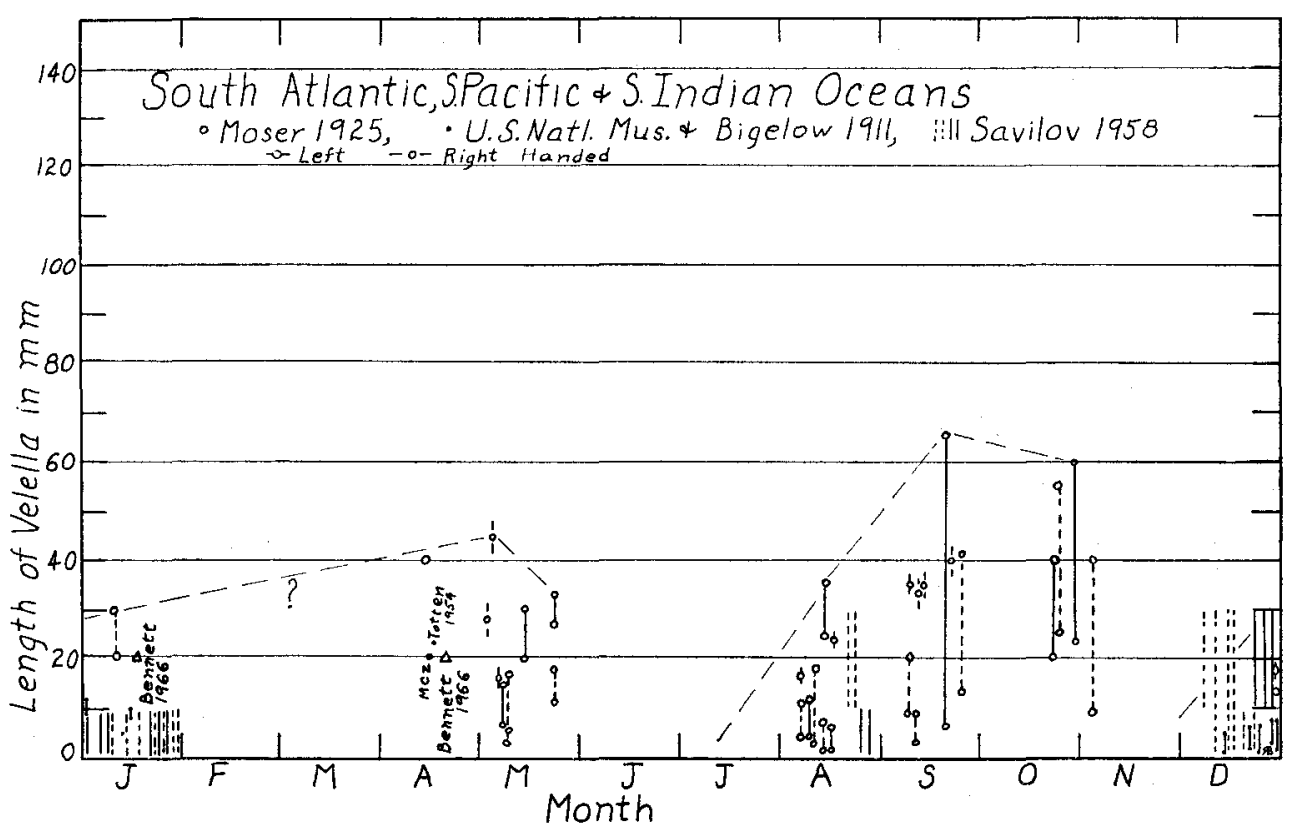

Fig. 4. Records of Velella in the South Atlantic, South Pacific and South Indian Oceans. The records of Savilov (1958) are interpolated-the exact sizes are not known. Museum of Comparative Zoology and Bennett (1966) records indicate present only—sizes not known. 
is shown in Fig. 1, in the Eastern North Atlantic and Mediterranean in Fig. 2, in the Western North Pacific in Fig. 3, and in the South Atlantic, South Pacific and South Indian Oceans in Fig. 4. Although Velella has been observed by naturalists for 150 years, records giving the three variables of date, location and size are scanty. The most extensive records are from the Eastern North Pacific and most of the discussion that follows applies primarily to that region. Rather amazingly there are so few records from the Western North Atlantic that they are not given here.

Despite the paucity of records and the fact that they cover a period of 122 years, there is an indication that the maximum size of Velella is reached twice in the year, first in late April or early May and again in late August to late October. The monthly summation of all records (Table 1) from the northern oceans (omitting the essentially continuous records of Savilov which are not easily comparable to the discrete records) indicates that the months of most frequent occurrence of Velella are March and August. The size frequency polygons shown in Fig. 5 indicate that only a single population or brood is present in the spring and a second brood in the fall.

Table 1. Summation of reports of Vellella in the Northern Oceans.

\begin{tabular}{lllllllllllllll}
\hline Month & J & F & M & A & M & J & J & A & S & O & N & D & \\
Number of Records & 2 & 6 & 11 & 8 & 5 & 5 & 6 & 11 & 4 & 4 & 4 & 2 \\
\hline
\end{tabular}

In the Eastern North Pacific only small individuals, less than ten to fifteen $\mathrm{mm}$ long, have been taken in December and January, while in the Eastern North Atlantic and southern oceans the largest specimens reported in November through January are about $30 \mathrm{~mm}$ long. There is a single record (U.S. National Museum) of a Velella $45 \mathrm{~mm}$ long in the Western North Pacific $\left(0.6^{\circ} \mathrm{N}\right.$. Lat., $174.5^{\circ}$ E. Long.) during the same period. In the Eastern North Pacific, specimens one to five $\mathrm{mm}$ long have been found on the sea surface from mid-December through early May and in August. In the Eastern North Atlantic and Mediterranean, individuals smaller than $5 \mathrm{~mm}$ have been reported from February through April, August, November and December. The November and December records are from Lo Bianco 1899 and earlier), but it is not clear if the specimens were taken from the surface or were larvae taken in deep net tows.

These data indicate that large velellas are missing from the sea surface during the late fall and early winter and for a shorter time in June. It seems to be a tradition among marine biologists to attribute the sporadic appearance of Velella along the coasts to changes in ocean currents and to the prevailing winds. For the mass strandings occassionally seen this may be so, however, fully 75 per cent of the records given in Figs. 1-4 are from oceanographic ships at sea working in more or less random fashion as far as the study of Velella is concerned. This is counting nine records of Lo Bianco as shore records and omitting 25 records of Savilov at sea. If Savilov's records are added in, then 80 per cent of the records are from ships at sea. It therefore seems reasonable to assume that the peaks in maximum size and in frequency 
of occurrence are real and not the result of collecting biased by seasonal changes in winds and currents. Probably the greatest bias in the data is the paucity of records in November, December and January when observations and collections at sea in the northern hemisphere are most difficult. I conclude that although Velella may be found on the sea surface much of the year, there is a marked, twice-yearly period of growth, abundance and reproduction of Velella.

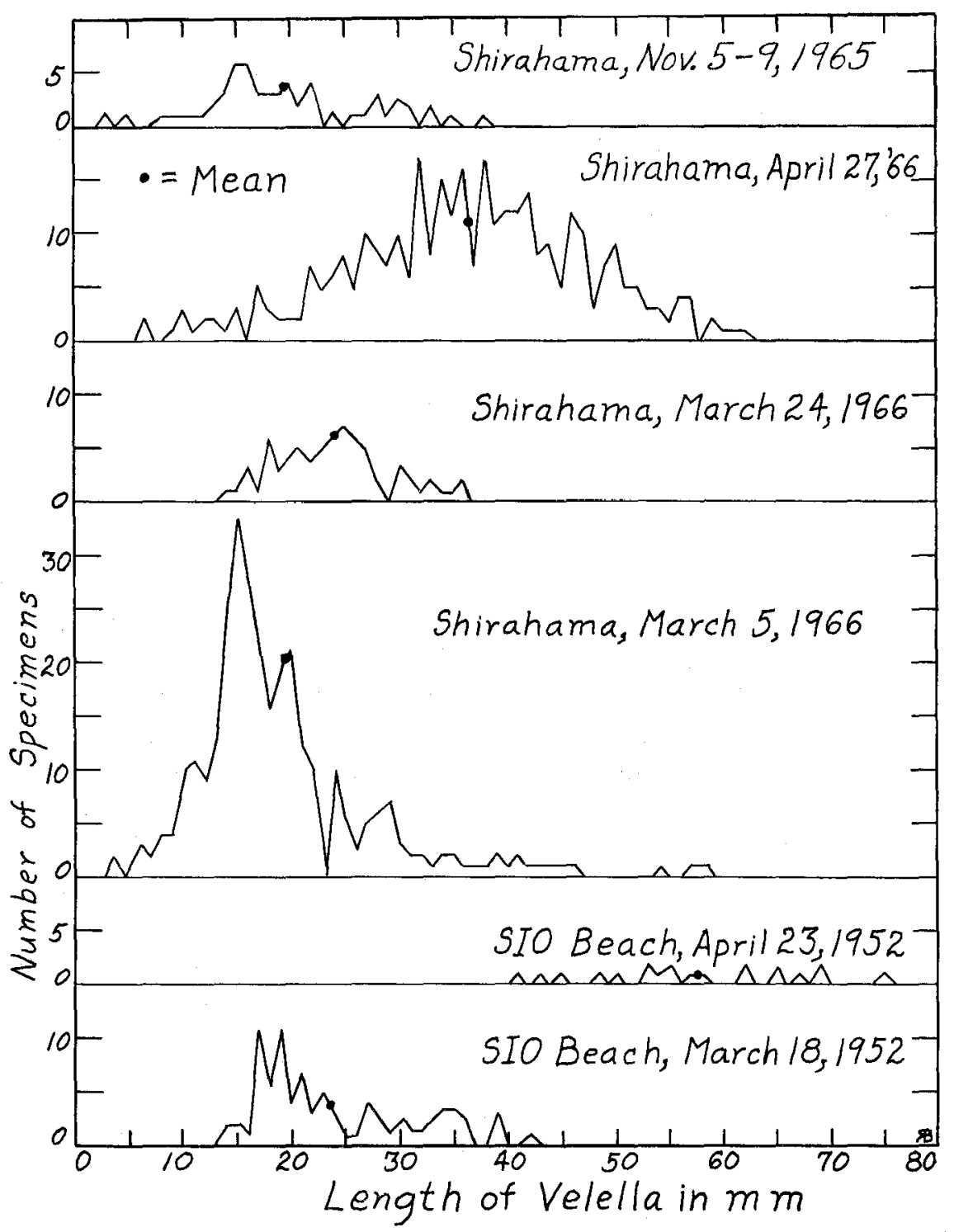

Fig. 5. Size frequency polygons of several stranded populations of Velella. Only a single brood is present in each case. 


\section{Growth Rates of Velella}

The growth rates of Velella can be estimated from the mean size of different populations in the same year and from the maximum size present at different times in the same year. Both methods involve several assumptions. For example, different mortality rates at different sizes would affect the estimates based on means, but as a first approximation the results of several simple calculations are given in Table 2. The growth rate estimates range from 0.3 to $0.9 \mathrm{~mm}$ increase in length per day with a rate of 0.4 to $0.5 \mathrm{~mm}$ per day most common. The tabular data are plotted graphically in Fig. 6. Although the growth rate estimated from the single giant individual $142 \mathrm{~mm}$ long has little to recommend it, the existence of a maximum in the absolute growth rate somewhere between 30 and $50 \mathrm{~mm}$ length is supported by independent data on the ratio of food mass to body mass of Velella. Specimens longer than $40 \mathrm{~mm}$ caught at sea off California had considerably less food per gram of body weight than specimens smaller than $40 \mathrm{~mm}$ (Bieri, 1961). The supersized specimen may have come from either the spring or late summer populations. In the growth rate calculation it was assumed to have come from the spring population. These rough rates can be used to estimate the life span of Velella. If a growth rate of onehalf $\mathrm{mm}$ per day for all sizes is assumed, then it would take 160 days or five months to reach a length of $80 \mathrm{~mm}, 120$ days or four months to reach a length of $60 \mathrm{~mm}$, and 90 days or three months to reach a length of $45 \mathrm{~mm}$. If, as indicated in Fig. 6, the high growth rates of 0.8 and $0.9 \mathrm{~mm}$ per day are used together with the $0.5 \mathrm{~mm}$ rates, it would take about 125 days or four months to reach a length of $80 \mathrm{~mm}$, the usual maximum size, and 75 days or two and one-half months to reach a length of $40 \mathrm{~mm}$. I regard these latter as the best estimates.

Table 2. Estimated Growth Rates of Velella

\begin{tabular}{|c|c|c|c|}
\hline $\begin{array}{l}\text { Graph } \\
\text { point } \\
\text { Fig. } 6\end{array}$ & $\begin{array}{l}\mathrm{mm} \text { of } \\
\text { length } \\
\text { per day }\end{array}$ & $\begin{array}{l}\text { Size range } \\
\text { of Velella }\end{array}$ & Basis of calculation \\
\hline a & 0.3 & $1-10 \mathrm{~mm}$ & $\begin{array}{l}\text { Mean lengths, Dec. 15-Jan. 15, Bigelow } \\
1911\end{array}$ \\
\hline a & 0.5 & $1-10 \mathrm{~mm}$ & $\begin{array}{l}\text { Maximum lengths, Dec. 15-Jan. 15, Bigelow } \\
1911\end{array}$ \\
\hline $\mathbf{b}$ & 0.5 & $10-30 \mathrm{~mm}$ & Maximum lengths, Jan. 7-Feb. 15, S.I.O. \\
\hline $\mathrm{c}$ & 0.9 & $20-60 \mathrm{~mm}$ & $\begin{array}{l}\text { Mean lengths, } 87 \text { specimens, Mar. 18-Apr. } \\
\text { 23, 1952, S.I.O. }\end{array}$ \\
\hline c & 0.9 & $20-60 \mathrm{~mm}$ & Maximum lengths, as above, S.I.O. \\
\hline d & 0.8 & $30-103 \mathrm{~mm}$ & Max. lengths, Feb. 15-May 10, 1950 S.I.O. \\
\hline $\mathbf{e}$ & 0.4 & $90-142 \mathrm{~mm}$ & Max. lengths, Mar. 29-Aug. 14, 1954 S.I.O. \\
\hline $\mathbf{f}$ & 0.5 & $3.5-58 \mathrm{~mm}$ & $\begin{array}{l}\text { Mean lengths, Mar. 5-Mar. 24, } 1966 \\
\text { Shirahama } 259 \text { specimens }\end{array}$ \\
\hline $\mathrm{g}$ & 0.4 & $6-62 \mathrm{~mm}$ & $\begin{array}{l}\text { Mean lengths, Mar. 24-Apr. 27, } 1966 \\
\text { Shirahama } 436 \text { specimens }\end{array}$ \\
\hline
\end{tabular}




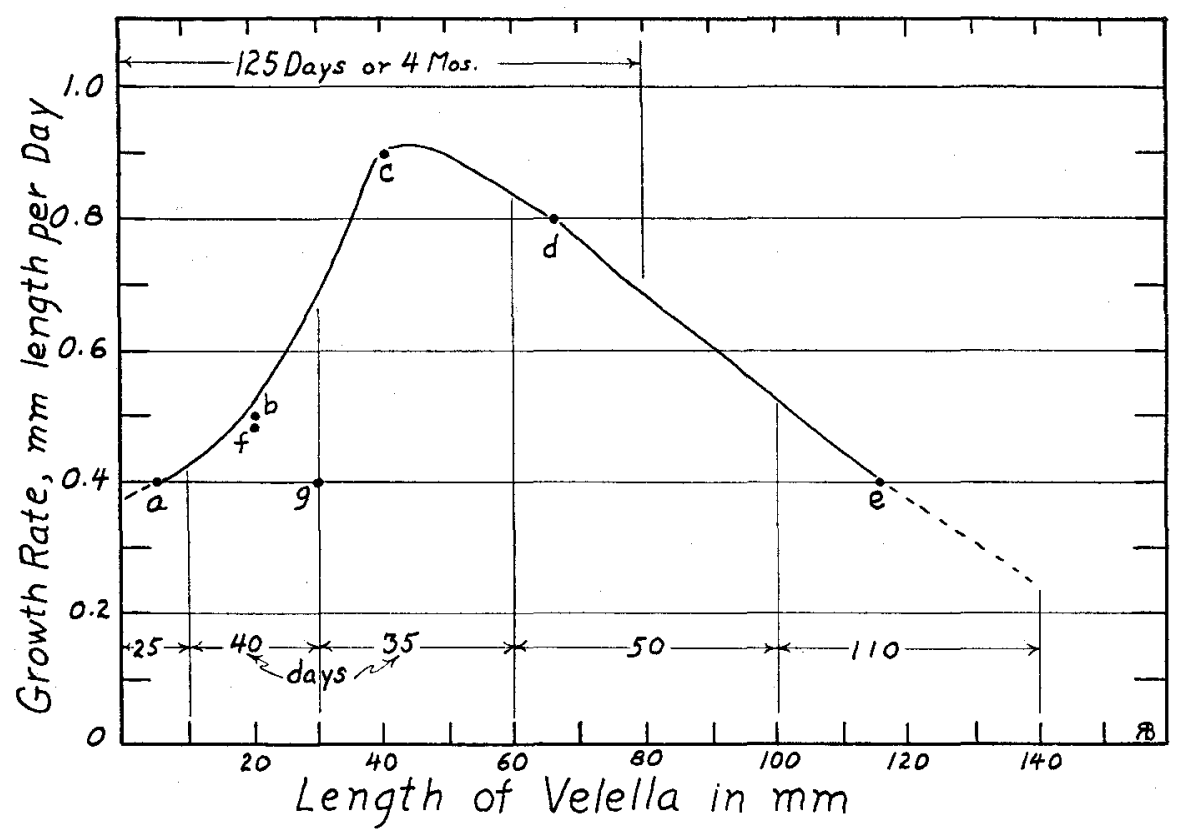

Fig. 6. Estimated growth rates of Velella as a function of total length. The basis of the points is given in Table 2. Point " $\mathrm{e}$ " is based on a single giant specimen. The estimated length of life is given in days.

\section{The Reproductive Gycle and Vertical Migration}

The size frequency diagrams of the medusae attached to different sizes of Velella (Fig. 7) indicate that velellas first release mature medusae at a length of about $20 \mathrm{~mm}$ but the maximum release of medusae occurs at lengths of $40 \mathrm{~mm}$ and larger. The released medusae or "chrysomitrae" average about $0.4 \mathrm{~mm}$ or greater in length, have

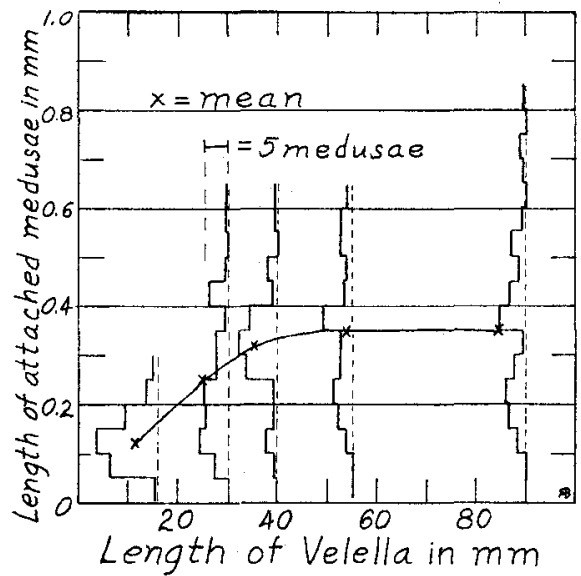

Fig. 7. Mean size of medusae attached to Velella as a function of length of Velella. Between 40 and $50 \mathrm{~mm}$ length, the rate of shedding of medusae becomes equal to the rate of formation of medusae. 
a relatively high density, and sink rapidly-on the order of $10 \mathrm{~cm}$ per minute in unstirred sea water.

Woltereck's report (1904) is still the only original account of the larval life. The medusae sink to depths of 600 to 1000 meters before they reproduce. He took a single carly conaria larva and many representatives of later stages at these depths in the Mediterranean. The larvae slowly rise to the surface and are one to two $\mathrm{mm}$ in diameter when they reach the surface as "rataria larvae"-small, nearly spherical velellas with no obvious asymmetry in the sail orientation. From a row boat $I$ have seen them on the sea surface off Baja California. They are very difficult to distinguish from minute bubbles.

The presence of only larval stages in the Eastern North Atlantic in November and the absence of all stages in the Eastern North Pacific in late October, November and early December indicates that the medusae and conaria larvae spend at least one month at depth and could possibly stay there as long as four months. Thus there are several possible yearly cycles alternating between the surface and the depths. For instance, the sequence could be five months on the surface and one month at depth occurring twice, $5,1,5,1$, or it could be $4,2,4,2$ or $3,3,3,3$. Because we know that the young reach the surface in the winter and early spring over a period of three to four months in the Eastern North Pacific (Fig. 1) and because the pronounced dips in size in June and December would be smoothed out by the $5,1,5,1$ pattern, it seems reasonable to rule out this sequence. The 4,2,4,2 pattern does not fit the Eastern North Pacific data very well, but the $3,3,3,3$ cycle does and is shown schematically in Fig. 8. Although Velella is found on the surface for five months early in the year and later in the year for another five months, the major part of the population goes up and down approximately every three to four months.

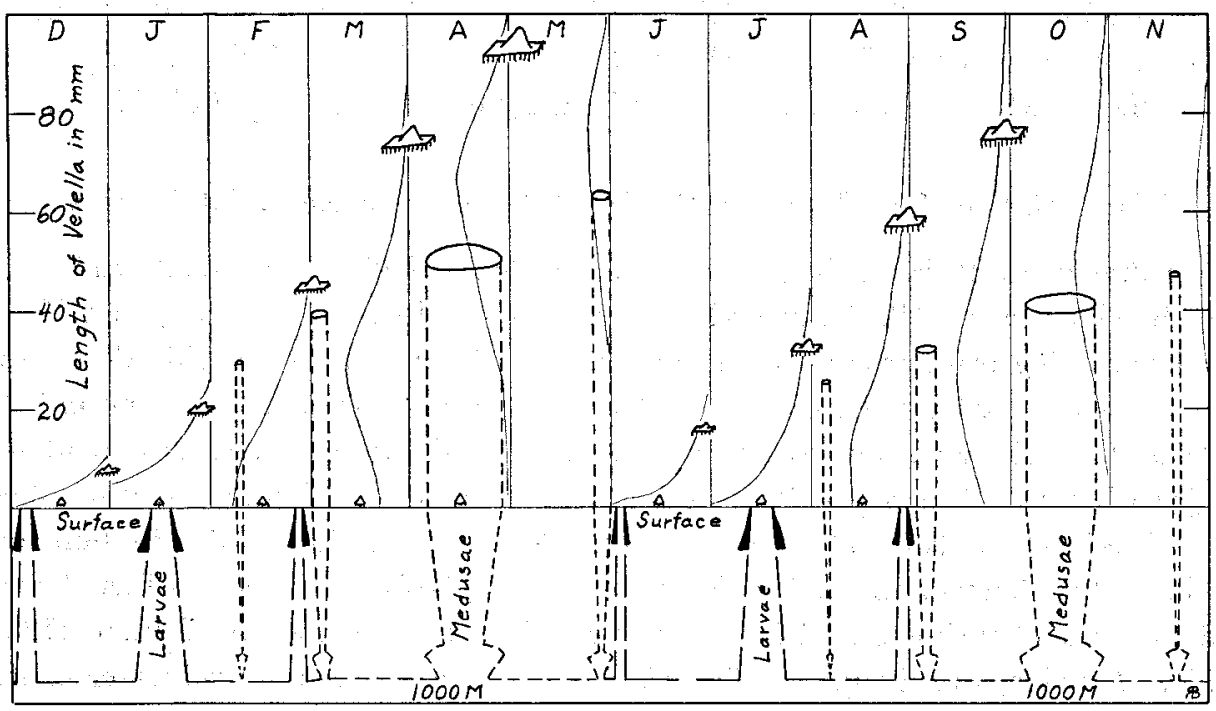

Fig. 8. Postulated cycle of growth and reproduction in Velella. The bulk of the medusae sink in April and October, while most of the larvae rise to the surface in January and July: 
What is the significance of the vertical migration? Why should Velella leave the surface in June? The winter sinking is understandable and is now well known for many kinds of zooplankton. Hardy (1956) suggested that the migration of Velella was to increase dispersal but sinking down below the winds to the slow and less turbulent currents of the depths slows dispersal. Indeed, this may well be part of the reason for the migration-to slow down dispersal. With growth and reproduction greatest in areas of abundant food, the sinking of the medusae to depths of 600 to 1000 meters would tend to hold the surface populations in the regions of high standing food crop.

The migration may also be phased with the spring and fall plankton blooms. The smaller maximum size reached by Velella in the fall lends support to the idea that Velella is tied to these blooms. Because the late summer, early fall food supply is generally lower than the spring supply, the growth rate of Velella may be slower in the second half of the year and at the same time the mortality higher, giving a generally smaller standing crop and smaller individuals of Velella in the fall. Variations in the success of this brood would affect the size of the following spring brood and thus add to the sporadic variations in their appearance.

Velella is unique among the sea surface hydrozoans in having commensal zooxanthellae (Hovase, 1922; Taylor, 1971). Although not yet demonstrated, it seems very likely that, as in benthic hydrozoans, the zooxanthellae contribute to the nutrition of Velella (Muscatine, 1971). The winter sinking may be due to the requirements of the commensal zooxanthellae. The zooxanthellae may well be more important in the nutrition and growth of the larger velellas than the food injested by the feeding organs (see Bieri, 1961). On the other hand, the summer sinking may be due to the weaker winds that would reduce the area of sea surface skimmed by Velella in its quest for food. In other words, the spring and late summer appearance of Velella on the sea surface may be the result of the combined nutritional requirements of wind to blow them along the surface in order to feed and of adequate light to support the zooxanthellae which seem to be necessary for the growth of the large individuals.

\section{The Relationship Between Horizontal and Vertical Distribution}

Although Velella is usually found between $40^{\circ} \mathrm{N}$. and $40^{\circ} \mathrm{S}$. latitude, it can be seen from Bigelow's chart (1911), reproduced with some additions as Fig. 9, that Velella is either missing from or is very rare in the general region of the Pacific Equatorial Water Mass. Savilov (1958) reported Velella very rare between the equator and $20^{\circ}$ N. latitude. The zone of rare occurrence or absence shown in Fig. 9 may extend into the Java Sea as Delsman (1923) reported Porpita is often seen there in great numbers while Velella seldom is found there. Thus Velella appears to have a distribution very similar to the chaetognath Sagitta bipunctata ( $=$ S. californica) as shown by Bieri (1959) and to the euphausiids Stylocheiron longicorne and S. shumii shown by Brinton (1962, 1975). It belongs to the group of species usually found in the central water masses and is probably most abundant around the edges of the central water masses where the standing crop of food is higher (Bieri, 1959). 


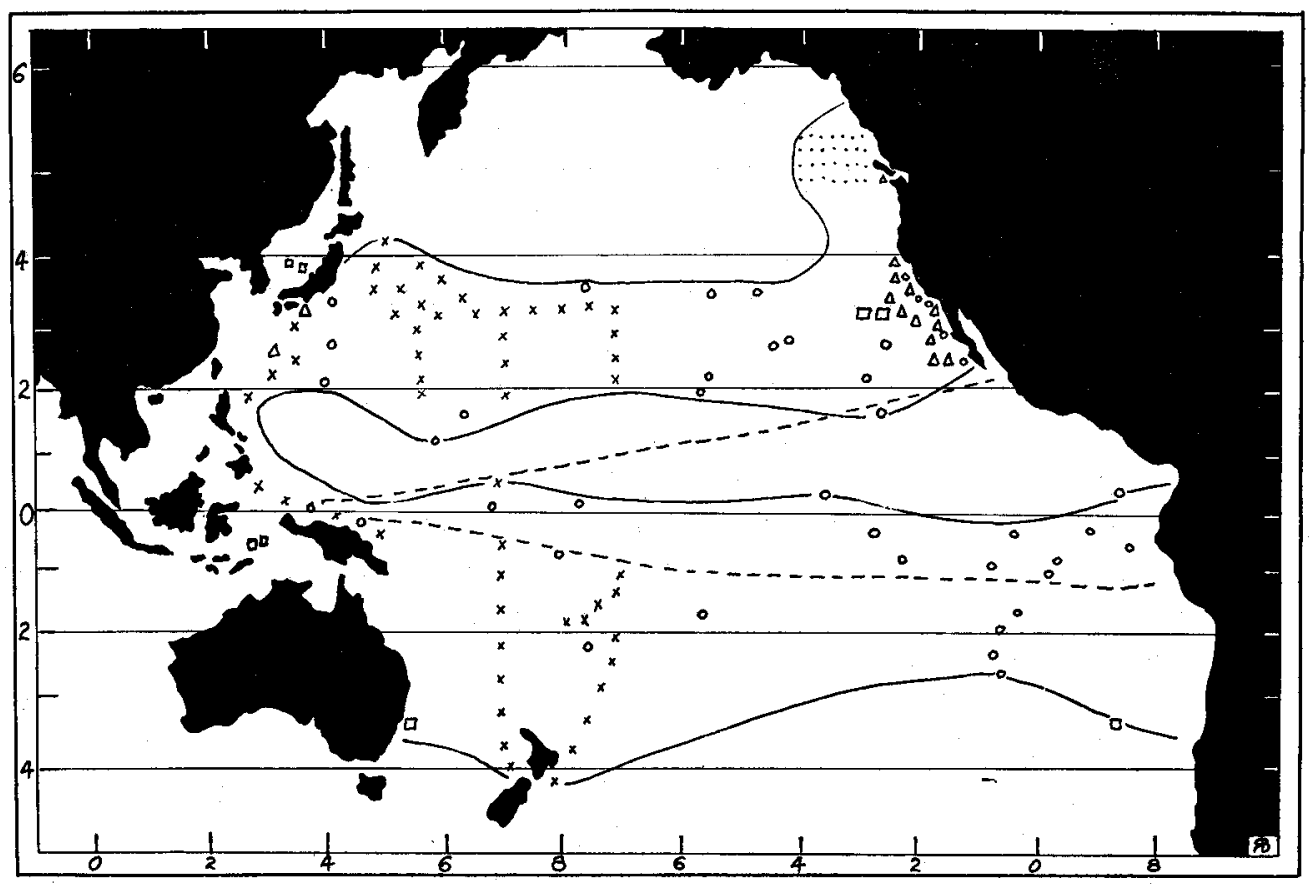

Fig. 9. Records of Velella in the Pacific. Circles are reported in Bigelow (1911). X's are interpolated from Savilov (1958). Triangles are records of the author. Squares are from west to east: Lens and Riemsdijk (1908), Nishimura (1958), Dakin, Bennett and Pope (1952), Bennett (1963), and Moser (1925). Dots are from Doe (1955). Velella is either missing or very rare in a band just north of the Equatorial Water Mass which is indicated by dashes (Sverdrup, Johnson and Fleming, 1949).

Although the surface distribution of Velella can be related in the north to the $15^{\circ}$ $\mathrm{C}$ surface isotherm (Savilov, 1958), and in the equatorial region to the 26 or $27^{\circ} \mathrm{C}$ surface isotherm, there may well be some control of the medusae and larvae by subsurface temperatures and salinities and off Central America by low oxygen. The over-all distribution must be due to a complex of factors including prevailing winds, water circulation, vertical migration, seasonal growth, fecundity and mortality. From the records presented above it seems that in the north temperate oceans it is largely a waste of time to search for Velella on the sea surface from November to January except with fine mesh nets and that from late May to early July one's chances of finding the elusive creature are quite low. The seasonal occurrence is a good excuse for the neustologist to stay home during the cold winter or better, to go south in search of contrary neusters. It also lets us make some first approximations of growth rate and life span, two factors of considerable value in understanding the ecology of these interesting animals. These rough estimates indicate that Velella, tied to the phytoplankton through the zooplankton link, has evolved a growth rate and reproductive cycle that is related to the seasonal abundance of its food and at the same time helps it to maintain itself in regions of maximum available food. 


\section{Summary}

1. Velella has two peaks in maximum size each year, one in late spring and the other in the fall. The maximum size is usually larger in the spring brood.

2. Growth rates calculated from the mean and maximum sizes of stranded populations and of specimens collected at sea indicate that the absolute growth rate is of the order of $0.5 \mathrm{~mm}$ increase in length per day, but varies with size and may at times reach one mm per day.

3. Size frequency polygons indicate that only a single population or brood is present in the spring and a second brood in the fall.

4. The peaks in maximum size, the estimated growth rates, and the size frequency polygons indicate that the bulk of the Velella population has a three to four month on the surface in spring, two to three month at depth, three to four month on the surface in late summer and fall and two to three month at depth in early winter cycle of growth and reproduction each year.

5. In the Pacific, Velella is closely associated with the central water masses. It is very rare in a zone in the northern part of the Pacific Equatorial Water Mass.

6. The sinking of the sexually reproducing medusae to depths of 600 to 1000 meters is interpreted as an adaptation to "hold" the populations in areas of high standing crop around the edges of the central waters and at the same time phase the surface population with the spring and fall plankton blooms.

\section{Acknowledgments}

M. Botesh helped with the early analysis of data. Drs. F. E. Bayer and T.E. Bowman kindly provided information on specimens stored in the U.S. National Museum. Dr. E. Deichman generously supplied information on the specimens deposited in the Museum of Comparative Zoology. Mr. H. Tanase helped in some of the beach collections at Shirahama and kept a careful eye out for strandings of Velella. Dr. T. Tokioka, H. Utinomi and S. Nishimura critically read the manuscript. To all these people I offer my sincere thanks for their interest and help.

\section{LITERATURE CITED}

Atkins, L.S. 1968. Velella spirans found in Co. Cork and Co. Kerry. Ir. Nat. J., 16: 24.

Bennett, I. 1966. Some pelagic molluscs and associated animals in south-eastern Australian waters. Jour. Malac. Soc. Aust., No. 9: 40-51.

Bieri, R. 1959. The distribution of the planktonic Chaetognatha in the Pacific and their relationship to the water masses. Limnol. Oceanogr., 4: 1-28.

1961. Post-larval food of the pelagic coelenterate, Vellella lata. Pac. Sci., 15: 553-556.

1966. Feeding preferences and rates of the snail, Ianthina prolongata, the barnacle, Lepas anserifera, the nudibranchs Glaucus atlanticum and Fiona pinnata, and the food web in the marine neuston. Publ. Seto Mar. Biol. Lab., 14: 161-170.

1977. A morphometric study of Velella (Hydrozoa) from different oceans. Publ. Seto Mar. Biol. Lab., (in press)

Bieri, R. and T.K. Newbury 1966. BOOBY II, a quantitative neuston sampler for use from small boats. Publ. Seto Mar. Biol. Lab., 13: 405-410. 
Bigelow, H.B. 1911. The Siphonophorae, reports on the scientific results of the expedition to the Eastern Tropical Pacific by the U.S. Fish Commission Steamer "Albatross", 1904-1905. Mem. Mus. Comp. Zool., Harv. Coll., 38: 175-401.

Bigelow, H.B. and M. Sears, 1937. Siphonophorae. Rep. Danish Oceanogr. Exped. 1908-10 to the Mediterranean and adjacent seas. II, Biol., 2: 1-144.

Bingham, F.O. and H.D. Albertson, 1974. Observations on beach strandings of the Physalia (Portuguese Man-of-War) community. The Veliger, 17: 220-224.

Brinton, E. 1962. The distribution of Pacific euphausiids. Bull. Scripps Inst. Oceanogr., 8: 51-270. 1975. Euphausiids of Southeast Asian waters. Naga Rept., 4(5): 1-287.

Chun, C. 1897. Die Siphonophoren der Plankton Exped. Ergeb. Plankton Exped., 2.

Dakin, W.J., I. Bennett and E. Pope, 1952. Australian seashores. Angus and Robertson, Sydney, $372 \mathrm{pp}$.

Delsman, H.G. 1923. Beiträge zur Entwicklungsgeschichte von Porpita. Treubia, 3: 243-266.

Doe, L.A.E. 1955. Offshore waters of the Canadian Pacific Coast. J. Fish. Res. Brd. Canada, 12: $1-34$.

Forbes, E. 1844. Report on the Mollusca and Radiata of the Aegrean Sea. Rept. Brit. Assoc. Adv. Sci., 13: 130-193.

Forrest, J.E. 1938. Velella spirans (Forskål) in the outer Hebrides. Scottish Naturalist, No. $229: 10$.

Hardy, A.C. 1956. The open sea. Houghton, Mifflin, Boston, 322 pp.

Hovasse, R. 1924. "Zooxanthella chattonii' (Endodinium chattonii). Bull. biol. Fr. Belg., 58: 34-38.

Issel, R. 1928. Sulle relazioni étologiche fra sifonofori (Velella spirans Esch.) e gasteropodi nudibranchi [Fiona marina (Forsk.)] nel Mare Ligure. Boll. Mus. Zool. Anat. Comp., Univ. Genova, 8: 1-7.

Kropp, B. 1931. The pigment of Velella spirans and Fiona marina. Biol. Bull., 60: 120-123.

Lebour, M.V. 1947. An interesting young Velella in the Plymouth plankton. Journ. Mar. Biol. Assoc. U.K., 26 : 548-550.

Lens, A.D. and T. van Riemsdijk, 1908. The Siphonophora of the Siboga Expedition. Siboga Exped., 9:1-130.

LoBianco, S. 1899. Notizie biologiche riguardanti specialmente il periodo di maturità sessuale degli animali del golfo di Napoli. Mitteil. Zool. Stat. Neapel, 13: 448-573.

1909. Notizie biologiche riguardanti specialmente il periodo di maturità sessuale degli animali del Golfo di Napoli. Mitteil. Zool. Stat. Neapel, 19(4): 513-761.

Moser, F. 1925. Die Siphonophoren der deutschen Südpolar Expedition 1901-03. Deut. Südpolar Exped., 17 (Zool. 9): 1-541.

Muscatine, L. 1971. Endosymbiosis of algae and coelenterates. In Exper. Coel. Biol. ed. by H.M. Lenhoff, L. Muscatine and L.V. Davis, U. Hawaii Press, 179-191.

Nishimura, S. 1958. Quelques remarques sur l'ingestion du Salpe, Salpa fusiformis Cuvier, chez le Maquereaux Pêchés dans le Mer du Japon Orientale. Ann. Rept. Jap. Sea Reg. Fish. Res. Lab., No. 4: 105-112.

Savilov, A.I. 1958. Pleuston of the western part of the Pacific Ocean. Doklady Akad. Nauk SSSR, 122(6): 1014-1017. (in Russian)

Shanock, J.T.R. 1969. Stranded jelleyfish at Cape Clear Isl. Ir. Nat. J., 16(8): 244.

Spagnolini, A. 1870. Catalogo degli Acalefi del Golfo di Napoli, I. Sifonofori, Milano, pp. 1-46.

Stephen, A.C. (ed.) 1936. Notes on some interesting animals stranded on the west coast of Scotland during the summer of 1935. Scottish Naturalist, p. 27.

Sverdrup, H.U., M.W. Johnson and R.H. Fleming. 1949. The Oceans. Prenctice-Hall, New York, $1087 \mathrm{pp}$.

Taylor, D.L. 1971. Ultrastructure of the "Zooxanthella" Endodinium Chattonii in situ. Journ. Mar. Biol. Assoc. U.K., 51:227-234.

Tregouboff, G. and M. Rose. 1957. Manual de planktologie méditerraneén. Centre nat. Rech. Paris, 2 vols. Anthomedusae: 273-292, 335-377.

Totten, A.K. 1954. Siphonophora of the Indian Ocean together with systematic and biological notes on related specimens from other oceans. Discovery Reports, 27: 1-162.

Wilson, D.P. 1948. The Portuguese man-of-war, Physalia physalis L., in British and adjacent seas. Journ. Mar. Biol. Assoc. U.K., 27: 139-172. 
Woltereck, R. 1904. Ueber die Entwicklung der Velella aus einer in der Tiefe vorkommenden Larve. Zool. Jahrb., Supp. 7, Festschrift A. Weissmann: 347-372.

1905. Bemerkungen zur Entwickelung der Narcomedusen und Siphonophoren. Verhandl. der Deutsch Zoologischen Gesellschaft: 106-122.

Woodcock, A.H. 1956. Dimorphism in the Portuguese man-of-war. Nature, 178: 253-255. 